\title{
PERAN DINAS KOPERASI USAHA MIKRO DAN PERDAGANGAN DALAM PENGAWASAN DISTRIBUSI PUPUK BERSUBSIDI
}

\author{
Yohanes Roni, Dody Setyawan \\ Program Studi Administrasi Publik, Fakultas Ilmu Sosial dan Ilmu Politik \\ Universitas Tribhuwana Tunggadewi \\ e-mail: yohanesroni021@gmail.com
}

\begin{abstract}
Abstrak: Penelitian ini dilakukan karena temuan pada surat kabar yang menunjukan bahwa petani yang tergabung dalam kelompok tani tidak mendapat pupuk bersubsidi, padahal seharusnya petani tersebut memperoleh fasilitas pupuk bersubsidi seperti rekannya yang tergabung dalam kelompok tani. Tujuan dari penelitian ini adalah untuk mendeskripsikan Pengawasan Distribusi Pupuk Bersubsidi di Kota Batu, faktor pendukung dan penghambat pada Dinas Koperasi, Usaha Mikro dan Perdagangan dalam pengawasan distribusi pupuk bersubsidi di kota Batu. Hasil penelitian ini menunjukan bahwa Dinas Koperasi, Usaha Mikro dan Perdagangan Kota Batu berperan cukup baik dalam mengawasi distribusi pupuk bersubsidi pada wilayah kerjanya, sebab Dinas tersebut telah memenuhi 3 tahap pengawasan yakni menetapkan standar, mengukur kinerja, dan melakuan perbaikan. Pengawasan didukung oleh Komisi Pengawasan Pupuk dan Pestisida Kota Batu dan terjalinnya koordinasi yang baik dari instansi lainnya.
\end{abstract}

Kata Kunci: Pengawasan; Distribusi; Pupuk Bersubsidi

\begin{abstract}
This research was carried out because of the findings in the newspaper which showed that farmers who were members of the farmers group did not receive subsidized fertilizer, even though the farmers should get subsidized fertilizer facilities like their peers who were members of the farmer groups. The purpose of this study is to describe the Supervision of Subsidized Fertilizer Distribution in Batu City, supporting and inhibiting factors in the Department of Cooperatives, Micro Business and Trade in controlling the distribution of subsidized fertilizers in Batu. The results of this study indicate that the Department of Cooperatives, Micro Enterprises and Trade of Batu City have a fairly good role in overseeing the distribution of subsidized fertilizers in their working areas, because the Office has fulfilled 3 stages of supervision namely setting standards, measuring performance, and carrying out improvements. Supervision is supported by the Batu City Fertilizer and Pesticide Monitoring Commission and good coordination from other agencies.
\end{abstract}

Keywords: Supervision; Distribution; Subsidized Fertilizer

\section{PENDAHULUAN}

Indonesia merupakan negara agraris, yang mana sumber penghidupan dan penghasilan masyarakat bertumpu pada sektor pertanian. Sektor Pertanian dapat dikatakan sebagai lapangan pekerjaan yang paling banyak menyerap tenaga kerja Indonesia. Hal ini dapat dilihat dari penyampaian Kepala BPS, Suhariyanto yang menyebutkan, pada triwulan pertama 2018, terdapat tiga lapangan pekerjaan yang memiliki tenaga kerja terbanyak, yaitu, : Pertama, sektor Pertanian, Kehutanan dan Perikanan yang memiliki persentase sebesar 30,46 persen atau kira - kira sebanyak 38,70 juta orang. Kedua, sektor Perdagangan memiliki persentase sebesar 18,53 persen atau kira - kira sebanyak 23,55 juta orang. Ketiga, sektor Industri Pengolahan memiliki persentase sebesar 14,11 persen atau kira - kira sebanyak 17,92 juta orang (https://tirto.id, 2019). 
JISIP: Jurnal Ilmu Sosial dan Ilmu Politik

ISSN. 2442-6962

Vol. 9 No. 1 (2020)

Pemerintah sebagai penyelenggara negara tentu menyadari bahwa sektor pertanian memiliki potensi yang besar dalam meningkatkan kesejahteraan dan mewujudkan kehidupan yang lebih baik, oleh sebab itu pemerintah berupaya memberikan bantuan pada sektor pertanian, agar dapat berjalan dengan lebih baik. Hal ini dapat dilihat melalui Undang-Undang Republik Indonesia Nomor 19 Tahun 2013 Tentang Perlindungan dan Pemberdayaan Petani, pada pasal 21 ayat 1 yang menjelaskan bahwa, Pemerintah dan Pemerintah Daerah dapat memberikan subsidi bibit tanaman, bibit/bakalan ternak, pupuk, dan alat serta mesin pertanian bagi kebutuhan petani.

Pupuk bersubsidi yang disediakan oleh pemerintah bagi para petani mrerupakan salah satu bentuk pelayanan publik. Sebab pada Undang - Undang Nomor 25 tahun 2009 tentang Pelayanan Publik, pasal 5 ayat 1 yang menjelaskan bahwa, pelayanan publik terdiri atas pelayanan barang publik, pelayanan jasa publik dan pelayanan administratif. Diantara ketiga jenis pelayanan publik tersebut, penyediaan dan distribusi pupuk bersubsidi tergolong dalam jenis pelayanan barang publik. Hal ini dapat dibuktikan pada lampiran Undang - Undang Nomor 25 tahun 2009 tentang Pelayanan Publik, tepatnya penjelasan pasal 5 ayat 3 huruf c poin ke 2 menjelaskan pupuk bersubsidi tergolong barang publik yang diadakan untuk memenuhi misi Negara agar harga pupuk dijual lebih murah mendorong petani berproduksi.

Berdasarkan Permentan No. 47 tahun 2018, pasal 1 ayat 1 menjelaskan pupuk bersubsidi merupakan barang dalam pengawasan yang pengadaan dan penyalurannya mendapatkan subsidi dari pemerintah guna memenuhi kebutuhan petani. Oleh sebab itu pengawasan yang signifikan sangat dibutuhkan agar proses distribusi pupuk bersubsidi berjalan dengan lancar. George R. Terry dalam Mukarom dan Laksana (2018: 156) menjelaskan pengawasan sebagai mendeterminasi semua kegiatan yang sudah dilakukan, maksudnya mengevaluasi prestasi kerja dan apabila perlu, menerapkan tindakan - tindakan korektif sehingga hasil pekerjaan sesuai dengan rencana yang ditetapkan. Sementara itu Mukarom dan Laksana (2018: 158) mengemukakan tiga bentuk klasifikasi pengawasan yakni: 1) pengawasan langsung dan tidak langsung 2) pengawasan preventif dan represif 3) pengawasan internal dan eksternal.

Berdasarkan Peraturan Menteri Perdagangan Nomor 15 tahun 2013 tentang Pengadaan dan Penyaluran Pupuk Bersubsidi untuk Sektor Pertanian, pasal 1 ayat 7 sampai 9 menjelaskan terdapat 3 pihak yang berperna dalam proses pengadaan dan distribusi pupuk bersubsidi, yakni produsen (sebagai pihak penyedia pupuk bersubsidi), distributor (sebagai pihak penyalur tingkat Kabupaten/Kota), dan pengecer (pihak penyalur tingkat kecamatan dan desa). Sementara itu pada peraturan yang sama pasal 25 ayat 2 menjelaskan bahwa terdapat beberapa pihak yang memiliki kewenangan dalam melakukan pengawasan, yakni PT. Pupuk Indonesia, Produsen, Komisi Pupuk dan Pestisida di tingkat Provinsi dan Kabupaten/Kota, Tim Pengawas Pupuk Bersubsidi Tingkat Pusat, Direktur Jenderal Perdagangan Dalam Negeri dan Direktur Jenderal Standarisasi dan Pelrindungan Konsumen, serta Kepala Dinas Provinsi maupun Kabupaten/Kota yang membidangi perdagangan.

Pada Koran Jawa Pos, edisi 8 September 2019, halaman 5 menerangkan bahwa dalam pelayanan distribusi pupuk bersubsidi di daerah Jawa Timur, khususnya Kota Batu, terdapat kendala yang dihadapi, yakni belum semua petani pada Kota Batu mendapatkan fasilitas pupuk bersubsidi, sebagai contoh Zaujan 52 tahun, yang terdaftar dalam anggota kelompok tani dan gabungan kelompok tani namun belum mendapatkan fasilitas pupuk bersubsidi. Padahal pada pasal 5, Peraturan Menteri Pertanian nomor 47 tahun 2018 tentang alokasi dan harga eceran tertinggi pupuk bersubsidi untuk sektor pertanian tahun anggaran 2019, menjelaskan bahwa, pupuk bersubsidi diberikan pada petani yang telah tergabung dalam kelompok tani. Dalam hal ini seharusnya petani yang terdaftar sebagai anggota kelompok tani dan 
JISIP: Jurnal Ilmu Sosial dan Ilmu Politik

ISSN. 2442-6962

Vol. 9 No. 1 (2020)

gabungan kelompok tani dapat menerima pupuk bersubsidi, namun kenyataannya terdapat petani pada Kota Batu belum menerima pupuk bersubsidi meski telah tergabung dalam suatu kelompok tani.

Permasalahan ketidaksesuaian jumlah pupuk bersubsidi yang terjadi pada Kota Batu, menjadi perhatian utama peneliti. Oleh sebab itu peneliti tertarik untuk melakukan penelitian mengenai peran Dinas Koperasi, Usaha Mikro dan Perdagangan dalam pengawasan distribusi Pupuk Bersubsidi di Kota Batu, agar melalui hasil penelitian tersebut dapat menjelaskan peran Dinas Koperasi, Usaha Mikro dan Perdagangan Kota Batu dalam mengawasi distribusi pupuk bersubsidi supaya dapat berjalan merata bagi para petani pada Kota Batu.

\section{METODE PENELITIAN}

Jenis penelitian yang digunakan adalah jenis penelitian kualitatif. Menurut Sugiyono (2015: 9) metode penelitian kualitatif adalah metode penelitian yang digunakan untuk meneliti pada kondisi objek yang alamiah, (sebagai lawannya adalah eksperimen) dimana peneliti adalah sebagai instrumen kunci, teknik pengumpulan data dilakukan secara triangulasi (gabungan), analisis data bersifat induktif, dan hasil penelitian kualitatif lebih menekankan makna daripada generalisasi. Dalam hal ini peneliti berupaya untuk mendeskripsikan fenomena - fenomena yang terjadi dalam Dinas Koperasi Usaha Mikro dan Perdagangan saat melakukan pengawasan distribusi pupuk bersubsidi di Kota Batu.Penelitian ini dilakukan pada Kantor Dinas Koperasi, Usaha Mikro dan Perdagangan Kota Batu yang terletak pada Jalan Panglima Sudirman No. 507, Desa Pesanggrahan, Kecamatan Batu, Kota Batu, Jawa Timur 65313. Teknik penentuan informan yang digunakan peneliti adalah purposive sampling, Menurut Sugiyono (2015: 218 219) Purposive Sampling yakni teknik pengambilan sampel atau sumber data dengan pertimbangan tertentu. Dalam hal ini pertimbangan tertentu yang dimaksud yaitu pertimbangan kepada pihak yang memahami dan mengetahui kondisi objek penelitian, sehingga informan dalam penelitian ini meliputi Kepala Seksi Pembinaan dan Pengembangan Distribusi Perdagangan dan Karyawan Toko Morodadi. Sementara itu untuk Jenis data yang dikumpukan meliputi data primer dan sekunder. Data primer meliputi data yang langsung diperoleh dari informan, sedangkan data sekunder meliputi datanya diperoleh melalui orang lain atau dokumen. Oleh sebab itu teknik pengumpulan data yang digunakan meliputi : a) wawancara b) observasi c) dokumentasi. Setelah data dikumpulkan, maka selanjutnya data akan dianalisis dengan tahapan yang terdiri reduksi data, penyajian data dan penarikan kesimpulan. Kemudian untuk menguji kebenaran data tersebut, maka peneliti menggunakan teknik keabsahan data triangulasi teknik yakni menguji kredibilitas data dilakukan dengan cara mengecek data kepada sumber yang sama dengan teknik yang berbeda (Sugiyono, $2015: 127$ ).

\section{HASIL DAN PEMBAHASAN \\ Menetapkan Standar}

Menurut Schermerhorn dalam Wibowo (2019: 199 - 200), Standar harus ditetapkan untuk mengukur penyelesaian pekerjaan. Input standard mengukur usaha kerja menuju pada tugas kinerja. Output standard mengukur hasil kinerja dalam bentuk kuantitas, kualitas, biaya, atau waktu. Sementara Menurut Maman Ukas dalam Mukarom dan Laksana (2018:162) ukuran (standar) menyajikan bentuk bentuk yang diminta. Standar ukuran ini bisa nyata, tidak nyata, umum ataupun khusus, tetapi selama seseorang masih menganggap bahwa hasilnya adalah seperti yang diharapkan. Dalam hal ini menerangkan bahwa menetapkan standar berarti menetapkan suatu ukuran yang nanti akan menjadi tolok ukur 
JISIP: Jurnal Ilmu Sosial dan Ilmu Politik

ISSN. 2442-6962

Vol. 9 No. 1 (2020)

keberhasilan suatu pekerjaan agar pekerjaan sesuai dengan yang diharapkan.. dengan demikian, suatu pekerjaan dikatakan berhasil apabila memenuhi standar yang telah ditetapkan.

Berdasarkan hasil penelitian yang telah peneliti lakukan, menunjukan bahwa Dinas Koperasi Usaha Miro dan Perdagangan Kota Batu menetapkan bahwa buku laporan bulanan penyaluran pupuk bersubisidi yang diserahkan distributor sebagai standar dalam melakukan pengawasan terhadap distribusi pupuk bersubsidi. Dalam hal ini, buku laporan bulanan penyaluran pupuk bersubisidi yang dijadikan standar dalam pengawasan distribusi pupuk bersubsidi tersebut, memuat data penyaluran pupuk bersubsidi. Data - data tersebut meliputi data alur penyaluran pupuk bersubsidi, data rekapitulasi laporan bulanan pengecer, data hasil verifikasi dan validasi pupuk bersubsidi tim kecamatan, serta data berita acara serah terima pupuk bersubsidi. Data - data tersebut dijadikan sebagai ukuran dalam melihat keberhasilan distribusi pupuk bersubsidi melalui perbandingan antara data penyaluran pupuk bersubsidi oleh distributor dengan data berita acara serah terima pupuk bersubsidi.

\section{Mengukur Kinerja}

Menurut Schermerhorn dalam Wibowo (2019: 199 - 200) mengukur kinerja harus dilakukan hati hati untuk dapat mendokumentasikan hasil. Pengukuran harus akurat untuk meneropong perbedaan antara apa yang sebenarnya terjadi dan apa yang telah direncanakan sebelumnya (standar). Tanpa pengukuran, tidak mungkin terjadi pengawasan yang efektif. Berdasarkan pendapat tersebut, Pengukuran kinerja dapat diartikan sebagai langkah pengawasan yang dilakukan dengan cara melakukan pemeriksaan pada kinerja yang dilakukan, kemudian diukur dengan standar yang telah ditentukan. Apabila hasil pemeriksaan memenuhi standar, maka pekerjaan tersebut berhasil dilaksanakan dengan baik, akan tetapi apabilahasil pemeriksaan menyimpang dari standar, maka pekerjaan tersebut belum terlaksana dengan baik. Pengawasan distribusi pupuk bersubsidi yang dilakukan oleh Dinas Koperasi Usaha Mikro dan Perdagangan Kota Batu terfokus pada proses distribusi dari Lini III dan Lini IV. Dalam hal ini Dinas Koperasi Usaha Mikro dan Perdagangan Kota Batu berupaya untuk memastikan agar pupuk bersubsidi yang didistribusikan oleh Distributor dapat diterima oleh pengecer dengan waktu yang tepat, tempat yang tepat, jumlah yang tepat dan jenis pupuk bersubsidi yang tepat. Dinas Koperasi Usaha Mikro dan Perdagangan Kota Batu berperan mengawasi distribusi pupuk bersubsidi dalam dua bentuk dua bentuk pengawasan yakni pengawasan langsung dan pengawasan tidak langsung. Pengawasan langsung adalah melakukan pengawasan atau pemeriksaan di tempat pekerjaan dilakukan. Sementara itu pengawasan tidak langsung adalah pengawasan yang diadakan dengan mempelajari laporan - laporan yang diterima oleh pelaksana, dan mempelajari pendapat - pendapat masyarakat.Pengawasan tidak langsung ini dilakukan dengan cara memeriksa dokumen atau laporan tertulis (Mukarom dan Laksana, 2018: 158).

Berdasarkan hasil penelitian yang telah dilakukan, menunjukan bahwa Dinas Koperasi Usaha Mikro dan Perdagangan Kota Batu telah melakukan pengukuran kinerja sesuai dengan teori tahap pengawasan. Hal ini ditunjukan Dinas Koperasi Usaha Mikro dan Perdagangan Kota Batu melakukan pengukuran kinerja pada dua bentuk pengawasan yakni pengawasan langsung dan pengawasan tidak langsung. Pada pengawasan langsung, Dinas Koperasi Usaha Mikro dan Perdagangan Kota Batu melakukan pengukuran kinerja dalam kurun waktu 3 bulan sekali, dengan cara mendatangi toko - toko pengecer pupuk bersubsidi kemudian memeriksa persediaan pupuk yang diterima oleh pengecer tersebut untuk diukur dengan data penyaluran oleh distributor yang termuat dalam laporan bulanan penyaluran pupuk bersubsidi. Kemudian pada pengawasan tidak langsung, Dinas Koperasi Usaha Mikro dan Perdagangan Kota Batu juga melakukan pengukuran kinerja dalam kurun waktu setiap bulan, dengan cara 
JISIP: Jurnal Ilmu Sosial dan Ilmu Politik

ISSN. 2442-6962

Vol. 9 No. 1 (2020)

memeriksa laporan bulanan penyaluran Pupuk Bersubsidi membandingkannya dengan data pupuk bersubsidi yang diterima oleh pengecer yang juga termuat dalam laporan tersebut. Dari dua bentuk pengawasan tersebut, Dinas Koperasi Usaha Mikro dan Perdagangan Kota Batu cenderung intesif melakukan pengawasan tidak langsung daripada melakukan pengawasan langsung. Hal ini dibuktikan dari konfirmasi peneliti kepada salah satu pengecer (Toko Morodadi) yang menerangkan minimnya peran Dinas Koperasi Usaha Mikro dan Perdagangan dalam melakukan pengawasan secara langsung pada pengecer. Toko Morodadi mengungkapkan bahwa selama ini pengawasan secara langsung pada toko/kios pengecer terhadap persediaan stok dan distribusi pupuk bersubsidi lebih intensif dilakukan oleh Dinas Pertanian Kota Batu dari pada Dinas Koperasi Usaha Mikro dan Perdagangan. Dalam hal ini, Dinas Koperasi usaha Mikro dan Perdagangan Kota Batu melakukan pengawasan tidak langsung dengan cara mengecek kesesuaian data antara data pupuk bersubsidi yang di terima oleh pengecer dengan data pupuk bersubsidi yang didistribusikan oleh Distributor yang termuat pada laporan bulanan penyaluran pupuk bersubsidi. Sehingga Apabila data pupuk bersubsidi yang diterima Pengecer, menunjukan kesesuaian dengan data Distributor maka distribusi pupuk bersubsidi dikatakan berhasil, namun apabila kedua data tersebut menunjukan ketidaksesuaian, maka terjadi permasalahan dalam distribusi pupuk bersubsidi.

\section{Mengambil Tindakan Perbaikan}

Menurut Schermerhorn dalam Wibowo (2019: 199 - 200) Langkah terakhir dalam proses pengawasan adalah melakukan tindakan yang diperlukan untuk mengoreksi masalah atau membuat perbaikan. Manajer harus waspada pada masalah ketika kinerja aktual lebih rendah dari harapan. Namun demikian, juga harus waspada apabila terdapat peluang situasi dimana kinerja aktual bergerak lebih tinggi daripada apa yang diinginkan. Berdasarkan perdapat tersebut, dapat ipahami secara sederhana mengambil tindakan perbaikan merupakan langkah terakhir yang perlu dilakukan, sebab apabila memang terjadi aktivitas penyimpangan dalam pekerjaan, maka tindakan perbaikan akan mengarahkan kembali pekerjaan sesuai dengan standar yang telah ditentukan.

Berdasarkan hasil penelitian yang telah dilakukan, menunjukan bahwa Dinas Koperasi Usaha Mikro dan Perdagangan Kota Batu telah melakukan tindakan perbaikan sesuai dengan teori tahap pengawasan Schermerhorn. Hal ini ditunjukan melalui penjelasan Bapak Antok Hariono, S.H., MM yakni Kepala Seksi Pembinaan dan Pengembangan Distribusi Perdagangan pada Dinas Koperasi Usaha Mikro dan Perdagangan Kota Batu yang menyatakan bahwa pada saat terjadi penyimpangan dari salah satu pengecer yang menyalurkan pupuk bersubsidi tidak pada wilayah kerjanya, Dinas Koperasi Usaha Mikro dan Perdagangan Kota Batu menyerahkan temuan pengawasan tersebut untuk diproses sesuai hukum yang berlaku. Hal ini sesuai dengan Peraturan Menteri Perdagangan Nomor 15 tahun 2013 tentang pengadan dan penyaluran pupuk bersubsidi untuk sektor pertanian pasal 30 ayat 2 yang menjelaskan bahwa distributor dan pengecer yang menjual pupuk bersubsidi diluar wilayahnya akan dikenakan sanksi sesuai ketentuan peraturan perundang - undangan.

Kemudian selain dari pada itu, Bapak Antok Hariono, S.H., MM yakni Kepala Seksi Pembinaan dan Pengembangan Distribusi Perdagangan pada Dinas Koperasi Usaha Mikro dan Perdagangan Kota Batu juga menyatakan bahwa apabila dalam proses distribusi pupuk bersubsidi ditemukan tindakan menyimpang, maka Dinas Koperasi Usaha Mikro dan Perdagangan Kota Batu akan memberikan surat peringatan kepada pihak yang menyimpang, kemudian apabila peringatan tertulis tersebut tidak diindahkan, maka melalui koordinasi bersama Komisi Pengawas Pupuk dan Pestisida tingkat Kabupaten/Kota dapat merekomendasikan kepada instansi yang menangani penerbitan SIUP (Surat Izin 
JISIP: Jurnal Ilmu Sosial dan Ilmu Politik

ISSN. 2442-6962

Vol. 9 No. 1 (2020)

Usaha Perdagangan) untuk membekukan atau mencabut SIUP pihak yang menyimpang tersebut. Sehingga dengan demikian pihak yang terus menerus menyimpang dari standar akan menghilang dari alur distribusi, sehingga diharapkan distribusi dapat berjalan dengan sesesuai dengan rencana yang ditetapkan. Hal tersebut sesuai dengan pasal 28 dan 29 Peraturan Menteri Perdagangan Nomor 15 tahun 2013 tentang pengadan dan penyaluran pupuk bersubsidi untuk sektor pertanian. Namun menurut keterangan Kepala Seksi Pembinaan dan Pengembangan Distribusi Perdagangan, menyampaikan bahwa saat ini Dinas Koperasi Usaha Mikro dan Perdagangan Kota Batu tidak lagi memiliki wewenang untuk memiliki wewenang untuk pembekuan dan pencabutan SIUP. Semua wewenang tersbut kini diatur oleh Dinas Penanaman Modal Pelayanan Terpadu Satu Pintudan Tenaga Kerja Kota Batu. Dengan demikian apabila peringatan tertulis yang diberikan pihak Dinas tidak mampu memperbaiki kinerja pihak - pihak tertentu dalam distribusi pupuk bersubsidi, maka langkah selanjutnya adalah melakukan pembekuan dan pencabutan SIUP oleh Dinas Penanaman Modal Pelayanan Terpadu Satu Pintudan Tenaga Kerja Kota Batu atas rekomendasi dari Komisi Pengawas Pupuk Bersubsidi tingkat Kabupaten/Kota.

\section{Faktor pendukung Pengawasan Distribusi Pupuk Bersubsidi}

Pengawasan terhadap distribusi pupuk bersubsidi dapat berjalan lancar karena pengaruh beberapa faktor pendukung. Faktor pendukung pertama adalah hadirnya tim pengawas Pupuk Bersubsidi yang membantu pengawasan secara lebih efektif melalui terjun langsung ke lapangan. Tim tersebut adalah Komisi Pengawasan Pupuk dan Pestisida tingkat Kabupaten/Kota yang dibentuk oleh Bupati/Walikota (Keputusan Menteri Pertanian nomor 4 tahun 2019). Kehadian tim tersebut membantu Dinas Koperasi Usaha Mikro dan Perdagangan Kota Batu dalam pengawasan distribusi pupuk bersubsidi secara lebih efektif, sebab melalui tim tersebut, anggota dari Dinas Koperasi Usaha Mikro dan Perdagangan Kota Batu untuk terjun langsung ke lapangan guna melakukan pengawasan pada Distribusi pupuk bersubsidi.

Selain itu salah satu faktor pendukung lainnya adalah terjalinnya koordinasi yang baik antara setiap pihak yang terlibat dalam distribusi pupuk bersubsidi. Dalam hal ini Dinas Koperasi Usaha Mikro dan Perdagangan Kota Batu telah menjalin koordinasi yang baik dengan pihak - pihak yang melaksanakan penyaluran pupuk bersubsidi di wilayah kerjanya. Selain itu Dinas Koperasi Usaha Mikro dan Perdagangan Kota Batu juga menjalin koordinasi yang baik dengan Dinas Pertanian Kota Batu, sebab Dinas Pertanian merupakan Dinas yang bertanggungjawab dalam mengawasi penyusunan usulan RDKK pupuk bersubsidi.

\section{Faktor penghambat Pengawasan Distribusi Pupuk Bersubsidi}

Dinas Koperasi Usaha Mikro dan Perdagangan Kota Batu dalam pengawasan distribusi pupuk bersubsidi mengeluhkan bahwa penghambat dari pengawasan pupuk bersubsidi adalah terjadinya kesalahan atau kekeliruan petani dalam menyusun RDKK. Pihak Dinas menuturkan hal ini akan membuat stok pupuk bersubsidi terlihat kurang, padahal pupuk disalurkan dengan jumlah yang tepat, hanya saja karena ada kekeliruan dalam penyusunan RDKK, sehingga hal ini dapat mengakibatkan kelompok tani yang keliru dalam menyusun RDKK tidak mendapat stok pupuk karena kekeliruan RDKK yang mereka susun.

Selain Selain itu faktor penghambat lainnya adalah kurangnya partisipasi masyarakat dalam melakukan pengaduan tentang permasalahan pupuk bersubsidi, padahal apabila masyarakat berpartispasi dalam pengawasan maka pengawasan terhadap distribusi Pupuk Bersubsidi pasti akan menjadi lebih 
JISIP: Jurnal Ilmu Sosial dan Ilmu Politik

ISSN. 2442-6962

Vol. 9 No. 1 (2020)

efektif. Sehingga permasalahan yang tidak terdeteksi oleh pihak Dinas masih bisa diteksi lewat laporan masyarakat.

Kemudian berdasarkan observasi yang peneliti lakukan, salah satu faktor penghambat dalam pengawasan distribusi Pupuk Bersubsidi adalah kurangnya kepedulian dan keseriusan pegawai dalam mengawasi pupuk bersubsidi. Hal ini dapat dilihat dari tindakan pengawasan yang dilakukan oleh Dinas Koperasi Usaha Mikro dan Perdagangan Kota Batu yang meskipun mengetahui prinsip 6 tepat sebagai standar pengawasan penyaluran pupuk bersubsidi namun memeilih menggunakan laporan bulanan penyaluran pupuk bersubsidi sebagai patokan dalam melakukan pengawasan distribusi pupuk bersubsidi.

Sedangkan berdasarkan pengakuan pengecer, faktor penghambat dari pengawasan distribusi pupuk bersubsidi adalah Kekurang pahaman pengecer dalam memahami alokasi pupuk bersubsidi yang ditetapkan pemerintah. Hal ini mengakibatkan kurangnya stok pupuk yang dikuatirkan dapat menimbulkan kesalahpahaman terkait dugaan penyimpangan terhadap pengecer yang kekurangan stok pupuk tersebut.

\section{KESIMPULAN}

Pengawasan yang dilakukan oleh Dinas Koperasi Usaha Mikro dan Perdagangan Kota Batu tergolong dalam pengawasan tidak langsung, yakni melalui Laporan Bulanan Penyaluran Pupuk Bersubsidi yang memuat data distribusi pupuk bersubsidi dari Produsen, Distributor maupun Pengecer. Berdasarkan hasil penilitian, peneliti menyimpulkan Dinas Koperasi, Usaha Mikro dan Perdagangan Kota Batu berperan cukup baik dalam mengawasi distribusi pupuk bersubsidi pada wilayah kerjanya, yang dibuktikan dengan terpenuhinya 3 teori tahap pengawasan yakni menetapkan standar, mengukur kinerja, dan melakukan perbaikan. Hal ini ditunjukan Dinas Koperasi Usaha Mikro dan Perdagangan Kota Batu yang menjadikan Laporan Bulanan Penyaluran Pupuk Bersubsidi sebagai standar dalam pengawasan distribusi pupuk bersubsidi, yakni dengan cara memeriksa data pupuk bersubsidi yang diterima oleh Pengecer, kemudian diukur dengan data distribusi pupuk bersubsidi yang disalurkan oleh Distributor. Penyaluran pupuk bersubsidi dikatakan tepat sasaran ketika kedua data pupuk bersubsidi tersebut, menunjukan kesesuaian, namun penyaluran pupuk bersubsidi dianggap bermasalah ketika kedua data tersebut menunjukan ketidaksesuaian. Dalam proses pengawasan distribusi Pupuk Bersubsidi ketika ditemukan penyimpangan, Dinas Koperasi, usaha Mikro dan Perdagangan Kota Batu memanggil Distributor yang bersangkutan pada wilayah kerjanya untuk meminta informasi terkait, kemudian memberikan peringatan tertulis pada pihak yang bermasalah. Namun ketika peringatan tertulis tidak ditaati, maka diberikan peringatan tertulis terakhir oleh Komisi Pengawas Pupuk dan Pestisida Kota Batu. Sekalipun peringatan terakhir tidak ditaati, maka Komisi tersebut memberikan rekomendasi kepada Dinas Penanaman Modal Terpadu Satu Pintu dan Ketenagakerjaan Kota Batu untuk menerbitkan pembekuan bahkan pencabutan Surat Izin Usaha Perdagangan (SIUP) bagi pihak yang melakukan penyimpangan. (telah melakukan perbaikan).

Pengawasan distribusi pupuk bersubsidi oleh Dinas Koperasi, Usaha Mikro dan Perdagangan (Diskumdag) Kota Batu dipengaruhi oleh faktor pendukung maupun penghambat. Faktor pendukung pengawasan meliputi adanya dukungan dari Komisi Pengawasan Pupuk dan Pestisida Kota Batu serta koordinasi yang baik dari setiap pihak. Sedangkan faktor penghambat pengawasan meliputi, kekeliruan penyusunan Rencana Definitif Kebutuhan Kelompok (RDKK), kurangnya kesadaran pegawai Diskumdag Kota Batu untuk melakukan pengawasan pupuk bersubsidi dijiwai prinsip 6 tepat, kurangnya partisipasi masyarakat dalam melakukan pengaduan tentang permasalahan pupuk bersubsidi, serta kurangnya 
JISIP: Jurnal Ilmu Sosial dan Ilmu Politik

ISSN. 2442-6962

Vol. 9 No. 1 (2020)

sosialisasi tentang alokasi pupuk bersubsidi, sehingga menyebabkan pengecer tidak memahami alokasi yang ditetapkan.

\section{DAFTAR PUSTAKA}

Direktorat Penyusunan APBN, Direktorat Jenderal Anggaran. 2019. Informasi APBN 2019: APBN untuk

Mendorong Investasi dan Daya Saing melalui Pembangunan Sumber Daya Manusia. Jakarta:

Direktur Jenderal Anggaran

https://tirto.id/bps-jumlah-penduduk-bekerja-triwulan-i-2018-sebanyak-12707-juta-cJ5D

Jawa Pos. 8 September, 2019. Distribusi Pupuk Bersubsidi Dipersoal. hlm 5.

Keputusan Menteri Pendayagunaan Aparatur Negara nomor 63 tahun 2003 tentang Pedoman Umum Penyelenggaraan Pelayanan Publik

Keputusan Menteri Pertanian Republik Indonesia Nomor 4 tahun 2019 tentang pedoman teknis pelaksanaan penyediaan dan penyaluran pupuk bersubsidi tahun anggaran 2019

Moleong, Lexy J. 2018. Metodelogi Penelitian Kualitatif. Bandung: PT Remaja Rosdakarya.

Mukarom, Zaenal dan Muhibudin Wijaya Laksana. 2018. Manajemen Pelayanan Publik. Bandung: CV Pustaka Setia

Nugroho, R. H. (2016). Kebijakan Distribusi Pupuk Bersubsidi Di Sidoarjo. Dinamika Governance: Jurnal Ilmu Administrasi Negara, 6(1).

Peraturan Menteri Perdagangan Nomor 15 Tahun 2013 tentang Pengadaan dan Penyaluran Pupuk Bersubsidi untuk Sektor Petanian

Peraturan Menteri Pertanian Republik Indonesia nomor 47 tahun 2017 tentang alokasi dan harga eceran tertinggi pupuk bersubsidi untuk sektor pertanian tahun anggaran 2018

Rohman, A. (2018). Dasar-dasar Manajemen Publik. Malang: Empat Dua

Sadhana, Kridawati. 2012. Etika Birokrasi Dalam Pelayanan Publik. Malang: CV Citra Malang.

Safitri, M. A. (2013). Distribusi pupuk subsidi kepada petani tebu dalam perspektif manajemen publik (Studi pada koperasi unit desa di Sumberpucung Kabupaten Malang). Jurnal Administrasi Publik, 1(1), 102-109.

Sugiyono. 2015. Memahami Penelitian Kuatitatif, Kualitatif DAN R\&D. Bandung: Alfabeta.

Tirto. 2018. BPS: Jumlah Penduduk Bekerja Triwulan I 2018 Sebanyak 127,07 Juta. Diakses pada 5 Oktober 2019 dari

Undang - Undang Nomor 25 Tahun 2009 tentang Pelayanan Publik

Vidyanita, V. (2016). Kinerja birokrasi dalam penyaluran pupuk bersubsidi di Kecamatan Jombang. JISIP: Jurnal Ilmu Sosial dan Ilmu Politik, 5(1).

Wibowo. 2019. Manajemen dari Fungsi Dasar ke Inovasi. Depok: PT Rajagrafindo Persada 